\title{
Bemarkingsriglyne vir mikro-ondernemnigs
}

\author{
Thea Smit
}

\section{SUMMARY}

Many a microenterprise has failed because it did not pay attention to the marketing side of the business. The owner of a small business should have a marketing orientation if the business is to succeed. This marketing orientation comprises striving to satisfy the consumer and realising maximum profit as the two most important long-term goals of the business. The small-business owner should know what is meant when one talks about marketing. Longenecker et al (1994:190) describe the marketing of a small business as ... those business activities that relate directly to identifying target markets, determining the potential of the target market, and preparing, communicating and delivering some bundle of satisfaction to the target markets.

The planning and implementation of a marketing orientation demand thorough planning, known as the marketing planning process. McDonald (1992:3) sees the marketing planning process as ... deciding on a logical sequence of activities, leading to the setting of marketing objectives and the plans for achieving them. The result of suceessful marketing planning is a written marketing plan that covers all the elements of the marketing planning process.

Research undertaken by the author (Smit, 1997) revealed that businesses do not give special attention to planning a marketing strategy. The author subsequently compiled marketing guidelines for home-based microenterprises in the clothing manufacturing industry. These guidelines are summarised in this article.

Most owners of microenterprises base their decisions on intuition or "gut feel". This instinct is an important part of any marketing decision, but it is also necessary to base decisions on facts. The more information a business has, the better it will understand its market, customers and competitors (Machado, 1996:17). The most common way of getting that information is through marketing research.

One of the secrets of success in marketing research is to think carefully what information is needed and then to collect it. Once all the information has been collected, it is organised, summarised and simplified in order to be usable. Tables, charts and other visual aids make it easier to see and understand what the information means (Machado, 1996:28).
A marketing model has been developed and is used as a framework for the marketing guidelines (see Figure 1). The different components of the model are discussed below.

Analysis of the environments surrounding the business comprises an assessment of the internal environment to determine the business' strengths and weaknesses, and an assessment of the external environment to determine opportunities and threats in the marketplace. Internal or microenvironmental analysis starts with planning and formulating the business' overall mission, objectives and culture. It continues to plan and analyse the product and ability of and groups of interest in the business. The external environment of the business consists of the market and the macroenvironment. The business' competitors, its market and its suppliers are analysed, and so is the macroenvironment, which comprises the social, economic, political, physical and technological environments.

The next step in the strategic marketing planning process is to integrate the results of the environmental analyses into a written marketing plan. This requires the formulation of a marketing mission, marketing objectives and a marketing strategy.

The marketing strategy describes the unique ways in which the business plans to attain its marketing goals. Such a strategy consists broadly of three components:

- Segmentation of the market in order to select target markets

- Positioning the business in relation to its competitors in order to position its product and/or service most effectively

- Planning and coordination the four decisionmaking areas or marketing instruments, namely product, price, distribution and marketing communication (also known as the marketing mix).

Market segmentation enables the marketer to divide the heterogeneous market into smaller, homogeneous submarkets or market segments. This enables the marketer to develop a specific marketing mix for each market segment, leading to optimal satisfaction of market needs. Four factors are used to segment consumer markets, namely geographic, demographic, life-style and customer behaviour factors. The ultimate goal of market segmentation is to identify markets in 
which the business can compete. The identified segments are known as the business' target market. According to Machado (1996:40-43), a small business has three options or approaches to dealing with its target market, namely mass marketing, multisegment marketing and a concentrated or niche approach. Both Washer (1992) and Machado (1996:43) contend that the concentrated or niche approach is the better approach for microenterprises. According to this approach the business concentrates all its efforts on one or two small market segments or niches. This approach allows the microenterprise to specialise and also to make better use of its scarce resources.

After the business has selected its target market, it should try to position itself in such a way that this market perceives it to be better than its competitors. The main aim of positioning is to persuade the business' customers that its particular product or service will meet their unsatisfied needs. The microenterprise should carefully decide how it is going to gain this competitive advantage, because this positioning provides the basis and direction for the marketing mix. It also focuses the attention of the owner of the business and its employees on what the business is trying to achieve in the marketplace.

When the microenterprise has been positioned in the marketplace, it is time to develop the marketing mix, in other words to decide about the most effective composition of the four components of the marketing strategy, namely product, price, distribution and marketing communication. According to Hannagan in Terblanche (1993:180), an effective marketing strategy will ... weld the four variables together in order to satisfy customers' needs. Ideally this will have what can be described as a synergistic effect, so that the total combined effect will be greater than the sum of the parts.

Decisions regarding the product or sevice of the microenterprise are extremely important for the successful running of the business. These decisions help to achieve two things, namely to satisfy the requirements of the target market and to meet the objectives of the business itself (Adcock et al, 1993:153). Product decisions comprise decisions on product classification, the product/service mix, branding and trademarks, packaging and warranties.

Pricing is a crucial element of the marketing mix because profit implications affect the long-term success of any enterprise (Majaro, 1993:93; Machado, 1996:84). Many factors influence pricing decisions, for example cost, competition, type of product or service, image, supply and demand, and environmental factors such as legislation, taxes and exchange rates. Other deci- sions on pricing include different ways of pricing, discounts and credit.

Distribution is about finding the best outlet(s) for customers to receive the products and/or services the microenterprise offers. Distribution is establishing a system that gets the product to where the customer wants to buy it (Machado, 1996:108). The business has to decide on a channel of distribution which may be described as a ... system of people and organisations that get products or services from the producer to the customer (Hutt \& Stull, 1992:310). These people or organisations are often called middlemen or intermediaries. Distribution decisions include deciding on whether to use a direct or an indirect distribution channel and where the business is to be located.

Marketing communication consists of all the methods used by the microenterprise to communicate with its target market, including advertisements, sales promotion, publicity and personal selling. All these methods are used to create a certain image of the business. The main objectives of successful marketing communication are to inform, to persuade and to remind the target market of the business and its product or service. The microenterprise has to decide on effective communication methods and how the results of its marketing communication are to be measured.

The owner of a microenterprise should consider all the above aspects in formulating a marketing strategy or marketing plan. The effectiveness of this marketing plan should be evaluated from time to time to ensure success as it is always better to be proactive rather than reactive in the marketplace.

- Mrs T-E Smith

Department of Home Economics, University of Pretoria 


\section{INLEIDING}

'n Goeie, oorspronklike produk alleen is nie genoeg om sukses in ' $n$ onderneming te waarborg nie. Bemarkingsbeplanning is ' $n$ kritieke element in die ontwikkeling en bedryf van 'n onderneming. Juis dit word dikwels afgeskeep of totaal geïgnoreer deur eienaars van mikro-ondernemings soos dié wat kledingprodukte tuis vervaardig. Effektiewe bemarking in enige onderneming spreek twee kritieke aspekte aan, naamlik die verbruiker en die mededingers. Bemarking stel 'n onderneming in staat om mededingend en suksesvol te wees (Kaplan, 1989:73; Machado, 1996:1). Die eienaar van ' $n$ onderneming moet ' $n$ bepaalde bemarkingsoriëntasie openbaar wat strewe na verbruikerstevredenheid en maksimale wins as die ondernemings se twee belangrikste langtermyn-doelwitte.

Longenecker et al (1994:190) omskryf die bemarking van ' $n$ klein onderneming as ... those business activities that relate directly to identifying target markets, determining the potential of the target market, and preparing, communicating and delivering some bundle of satisfaction to the target markets. Bemarking is die proses waardeur potensiële verbruikers gevind word en waardeur alles wat in die onderneming gedoen of aan die verbruikers gebied word, daarop gemik is om hul behoeftes te bevredig.

Bemarking vereis deeglike beplanning, en dit word die bemarkingsbeplanningsproses genoem. McDonald (1992:3) beskryf dit as ... deciding on a logical sequence of activities, leading to the setting of marketing objectives and the plans for achieving them. Die resultaat van bemarkingsbeplanning is ' $n$ bemarkingsplan of -strategie wat stel wat die onderneming met sy bemarking hoop om te bereik, hoe dit bereik gaan word, en hoeveel investering dit gaan verg.

Uit navorsing deur die skrywer (Smit, 1997) het geblyk dat mikro-ondernemings in die klerevervaardigingsbedryf tuis (voortaan slegs mikro-ondernemings genoem) nie doelbewus aandag aan die beplanning van 'n bemarkingstrategie skenk nie. Aangesien die korrekte benadering tot bemarking ' $n$ onderneming kan maak of breek, is bemarkingsriglyne vir sulke ondernemings saamgestel. "Eienaar", "bestuurder" en "ondernemer" word as sinonieme gebruik. "Produk" verwys na die produk en/of diens wat gelewer word.

Bemarkings- en marknavorsing is ' $n$ belangrike onderdeel van bykans elke stap in die bemarkingsbeplanningsproses.

\section{BEMARKINGSNAVORSING}

Heelparty eienaars van mikro-ondernemings baseer hul besluite rakende die onderneming op intuïsie ("gut feel"). Enersyds is intuïsie ' $n$ belangrike deel van bemarkingsbesluitneming, maar andersyds behoort 'n ondernemer sy besluite op feite te baseer (Levinson \& Godin, 1994:4; Machado, 1996:17). Hoewel bemarkingsinligting nie korrekte besluite waarborg nie, kan dit bydra tot goeie en effektiewe besluite. Hoe meer inligting 'n onderneming het, hoe beter kan dit sy mark, verbruikers en mededingers verstaan (Longenecker et al, 1994:192). Hierdie inligting kan ingesamel word deur bemarkingsnavorsing te onderneem.

In suksesvolle bemarkingsnavorsing is die besluit oor watter inligting benodig word belangrik aangesien dit die data-insameling vergemaklik (Machado, 1996:21). Belangrike inligting vir 'n mikro-onderneming sluit die grootte van die mark, eienskappe en behoeftes van die gekose marksegment, koopgewoontes en -patrone van potensiële verbruikers, sterk en swak punte van mededingers, en algemene inligting oor markneigings in, byvoorbeeld verandering in die bevolking en verandering in vraagpatrone.

'n Bemarkingsmodel (Figuur 1) dien as raamwerk vir die bemarkingsriglyne. Hierdie model is aangepas uit ' $n$ model wat deur Terblanche (1993:71) volgens die modelle van Van der Walt et al (1996:31) en Kotler en Andreasen (1991:69) ontwikkel is.

\section{OMGEWINGSVERKENNING}

Omdat geen onderneming in 'n vakuum bestaan nie, begin elke bemarkingsbeplanningsproses met ' $n$ deeglike verkenning van die omgewing waarin die onderneming bedryf word.

Die benadering van bemarking as ' $n$ strategiese beplanningsproses veronderstel dat bemarking in twee omgewings plaasvind. Verkenning van die interne omgewing is nodig om bewus te wees van die onderneming se sterk en swak punte, en eksterne omgewingsverkenning is nodig om geleenthede en bedreigings te peil. Die bedoeling is om die onderneming se hulpbronne en sterk punte so op die mark te rig dat geleenthede benut en bedreigings betyds verhoed kan word.

\section{Interne omgewingsverkenning}

Voordat bemarkingsbeplanning en interne omgewingsverkenning begin, word veronderstel dat die eienaar reeds 'n oorkoepelende beplanning gedoen het ten opsigte van die onderneming se missie, doelstellings en kultuur.

\section{Missie, doelstellings en kultuur}

Lovelock (1984:160) omskryf die missie van 'n onderneming soos volg: ... it is a long-term statement of what the organization seeks to do and the rationale for its existence. Volgens Van der Walt et al (1996:46) word 'n missie opgestel aan die hand van die produk wat gelewer word, die belangegroepe wat gedien word, die wyse waarop die mark bedien word (tegnologie), en die bepaalde filosofie wat vir die bestuur, die werknemers en die gemeenskap geld. Elke onderneming begin met ' $n$ missie en het nie bestaansreg daarsonder nie. 


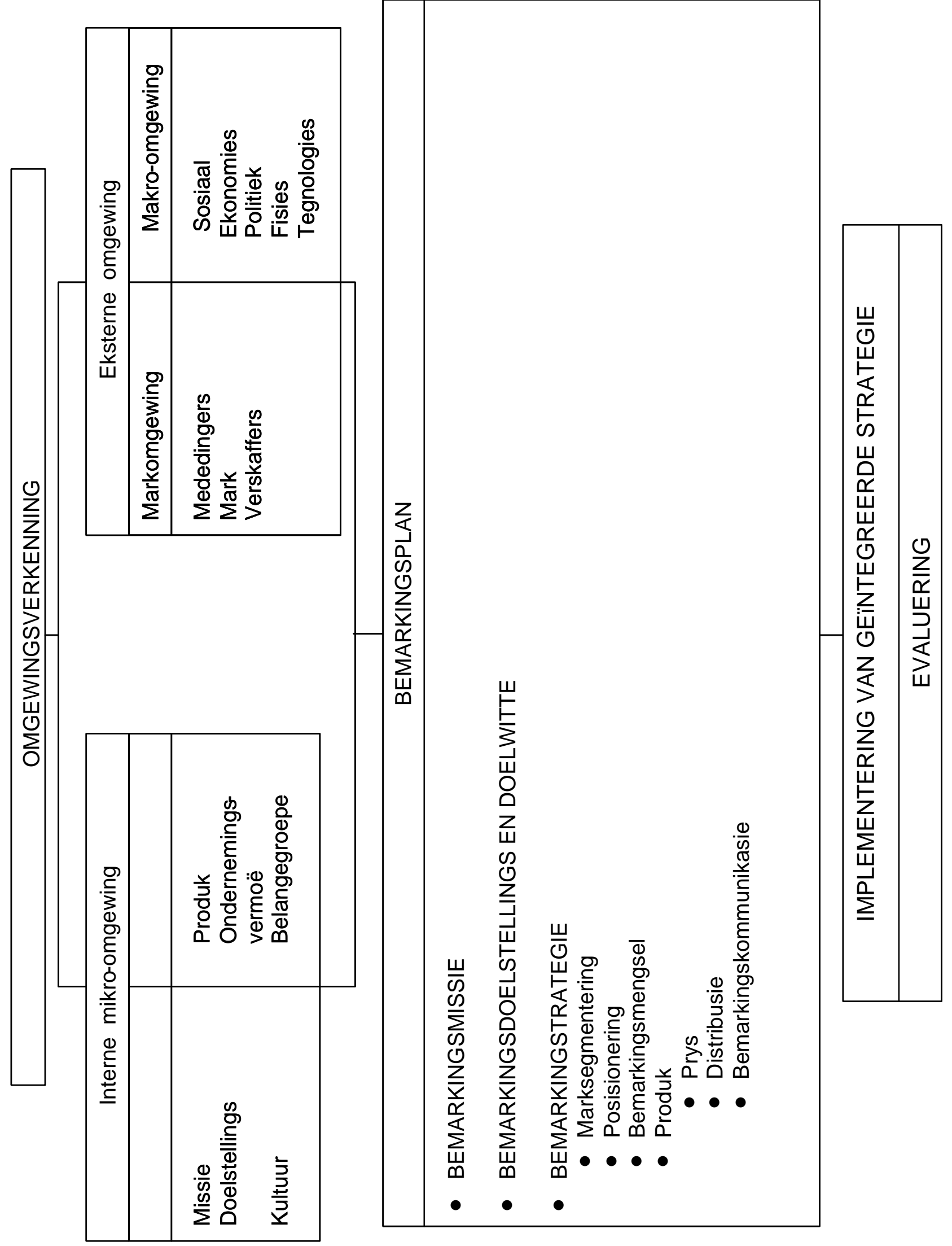

FIGUUR 1: $\quad$ BEMARKINGSMODEL (Smit, 1996:10,66) 
'n Missie fokus die onderneming se aandag op die primêre verbruikers (Kotler en Andreasen, 1991:73) en moet die volgende vrae beantwoord:

- Wat is die aard van die onderneming se produk/ dienslewering?

- Wie is die verbruikers en ander belangegroepe?

-Wat is hulle behoeftes?

- Hoe gaan hierdie behoeftes bevredig word?

' $n$ Missiestelling is motiverend - die personeel moet trots voel om met so ' $n$ onderneming geasssosieer te word - en ook onderskeidend - dit gee te kenne dat dinge hier anders en/of beter gedoen word. Hoewel 'n missie breed geformuleer word, moet dit nie onuitvoerbaar idealisties wees nie, anders verloor dit geloofwaardigheid in die oë van belangegroepe (Kotler \& Andreasen, 1991:73).

Die volgende is ' $n$ voorbeeld van ' $n$ missie vir ' $n$ kledingvervaardigingsonderneming wat tuis bedryf word:

"Die missie van $A B C$-onderneming is om besondere trourokke van uitstaande gehalte te ontwerp en te vervaardig na gelang van die unieke persoonlikheid en behoeftes van die bruid".

Die doelwitte van 'n onderneming volg direk uit die missie en dui spesifiek aan wat binne ' $n$ bepaalde tydperk bereik wil word. Van der Walt et al (1996) onderskei tussen oorkoepelende langtermyn- en/of strategiese doelwitte en doelwitte vir die korter termyn. Beide die lang- en korttermyndoelwitte moet aan die volgende vereistes voldoen:

- Die doelwitte moet spesifiek geformuleer en duidelik wees.

- Hulle moet realisties en bereikbaar wees.

- Hulle moet meetbaar wees.

- Hulle moet tydgebonde wees.

- Doelwitte moet in prioriteitsvolgorde gelys word.

Wanneer daar ' $n$ relatief algemene verbondenheid tot ' $n$ gemeenskaplike doelstelling in die onderneming is, word die volgende stappe in die omgewingsverkenning relevant.

\section{Produk, ondernemingsvermoë en belangegroepe}

Strategiese bemarkingsbeplanning sal nie suksesvol wees tensy die strategiese faktore, dit is die interne sterk en swak punte van die onderneming, begryp word nie. In die algemene taal word na 'n SWOTanalise verwys (strenghts, weaknesses, opportu-nities, threats). Die sterk en swak punte van die onderneming word aan die hand van die mark- en makro-omgewingsgeleenthede en -bedreigings beoordeel. Dit voorkom dat ' $n$ onderneming byvoorbeeld iets as 'n sterk punt identifiseer wat nie op die aanspreek van behoeftes in die eksterne omgewing van toepassing is nie.

Die produk wat die onderneming lewer, vorm die mid- delpunt van die onderneming se aktiwiteite. Daarvoor word die onderneming gestig, 'n organisasie gebou en mense en goedere byeen gebring (Marx et al, 1991:85), en daaruit word inkomste gegenereer.

Die produk word deeglik tydens die strategiese bemarkingsbeplanning bestudeer. Aangesien die produkvraagstuk reg deur die bestaan van die onderneming voorkom, word tydens die strategiese bemarkingsbeplanning besin oor die diversifikasie of inkrimping van die produkreeks wat die onderneming bied.

Die vermoë van die onderneming verwys na hulpbronne soos kapitaal en toerusting asook die menslike hulpbronne waaroor die onderneming beskik. Oorweging word tydens strategiese bemarkingsbeplanning geskenk aan die beskikbaarheid of die bekombaarheid van al die nodige middele om die produk te vervaardig of die diens te lewer. Daar word spesifiek gelet op kapitaalbelegging in die vorm van grondstowwe, geld of grond en geboue wat die onderneming nodig het asook die vermoë van die bestuur en werknemers om ' $n$ bepaalde produk te vervaardig of diens te lewer.

Aandag word geskenk aan belangegroepe in die onderneming en meer spesifiek aan die persoonlikheid, vaardigheid, persoonlike voorkeure, fisiese en geestelike vermoëns, ervaring en ander hoedanighede van die eienaar. Dit speel 'n vername rol in die uiteindelike sukses van die onderneming en ook in die persoonlike bevrediging van die eienaar. Die eienaar is egter nie die enigste belangegroep in die onderneming nie. Individuele werknemers wil ook graag hul behoeftebevrediging maksimeer en verwag daarom ' $n$ goeie inkomste, gesondheidsvoordele, sekuriteit, werksbevrediging en so meer.

Omdat ' $n$ onderneming soms handel dryf met kapitaal wat van ' $n$ buite-instelling afkomstig is, is die eksterne finansiers ook ' $n$ belangegroep om mee rekening te hou. Dié groep het versekering nodig dat die onderneming winsgewend is.

\section{Eksterne omgewingsverkenning}

Die verkenning van die eksterne omgewing het ten doel om geleenthede en bedreigings in die mark- en makro-omgewing te bepaal, en hierdie verkenning geskied saam met die interne analise van sterk en swak punte.

Die markomgewing Hierdie omgewing bestaan uit faktore in die onmiddellike omgewing wat 'n direkte invloed uitoefen op die onderneming se vermoë om die nodige hulpbronne te bekom en om die besigheid op 'n winsgewende wyse te bedryf. Die faktore in die markomgwing verskil van díe in die makro-omgewing omdat die eienaar meer beheer daaroor het. Die eienaar kan dus meer proaktief optree as in die geval van die makro-omgewing.

Die belangrikste faktore in ' $\mathrm{n}$ onderneming se markomgewing is sy mededingende posisie, die mark, en 
sy verskaffers van hulpbronne (Kotler, 1984:78-84; Pearce \& Robinson, 1985:108). Tydens strategiese bemarkingsbeplanning word die posisie van die onderneming met betrekking tot sy mededingers bepaal deur ' $n$ indringende studie van die optrede en aktiwiteite van hierdie mededingers te maak. So word inligting omtrent die winspotensiaal en groeimoontlikhede van die onderneming bekom.

Bemarkingsbeplanning definieer ook 'n duidelike beeld van die geografiese gebied wat die onderneming gaan bedien. Kennis van die mark stel die bestuur in staat om moontlike veranderinge in die grootte van die mark te voorsien en om vroegtydig voorsiening vir hulpbronveranderinge te maak. Die karaktereienskappe van die verbruikers van die betrokke produk word ook ondersoek.

Die verhouding tussen 'n onderneming en sy verskaffers is belangrik vir die voortbestaan daarvan. Verskaffers sluit leweransiers van grondstowwe sowel as verskaffers van sekere hulpdienste in.

Aansluitend hierby is die arbeidsmark en die onderneming se vermoë om werkers van die regte kwaliteit en kwantiteit te lewer, te trek en te behou. Die onderneming se reputasie as werkgewer asook sy loon- en salarisskale is in hierdie opsig belangrik.

Verkenning van die eksterne omgewing behels nie net ' $n$ evaluering van die markomgewing nie. Die makro-omgewing speel eweneens ' $n$ belangrike rol in 'n onderneming se besluitneming oor bemarkingstrategieë.

Die makro-omgewing Die makro-omgewing verwys na die totale eksterne omgewing wat die markomgewing direk of indirek beïnvloed. Die makro-omgewing bestaan uit die sosiale, ekonomiese, politieke, fisiese en tegnologiese omgewings (Kotler \& Armstrong, 1987:123-131; McCarthy \& Perrault, 1993:112-131; Schoell \& Guiltinan, 1993:34, 46, 56).

Die sosiale omgewing verwys na die grootte en verspreiding van die bevolking, en die gepaardgaande houdings, gedrag, gebruike en gewoontes wat inslag vind in die sosiale instellings waarmee die onderneming te doen kry. Aangesien die onderneming personeel in diens neem en sy produkte aan verbruikers lewer, word ook gekyk na die sosiale klimaat wat in waardestelsels en ideologieë geopenbaar word.

Die onderneming het ook ' $n$ verantwoordelikheid teenoor die gemeenskap en aspekte soos kwaliteitprodukte, goeie diens asook goeie diensvoorwaardes is hier ter sprake.

Die ondernemer moet bewus wees van ekonomiese verskynsels wat die bedryfstak waarin sy of haar onderneming bestaan, kan beïnvloed. Faktore soos die beskikbaarheid van krediet, rentekoerse, belasting, die inflasiekoers, en die invloed hiervan op verbruikersbesteding en groeikoerse is byvoorbeeld belangrik. In die strategiese bemarkingsbeplanningsproses word kennis geneem van hierdie faktore en die impak daarvan op die doelmatige funksionering van die onderneming om negatiewe invloede voortydig te kan bekamp en positiewe invloede te kan benut.

Die politieke omgewing omvat die owerheid wat die bedryf reguleer en die voorwaardes stel waaronder gewerk word. Wetlike aspekte, en die beginsels van bedryfsvryheid en ondernemingsbesit is belangrike elemente aangesien dit die ander faktore wat die ekonomiese omgewing uitmaak, beïnvloed. Politieke stabiliteit en doelwitte raak ' $n$ onderneming beide direk en indirek deurdat dit byvoorbeeld investering aanmoedig en belasting- en ander toegewings maak.

Die fisiese omgewing bestaan uit die natuurlike hulpbronne en die verbeterings en veranderings wat die mens aanbring, byvoorbeeld die beskikbare infrastruktuur.

Die tegnologie wat by ' $n$ onderneming se produk betrokke is, het ' $n$ invloed op die strategiese beplanningsproses. Die bestuur moet kennis dra van ontwikkelinge op tegnologiese gebied om te waak teen veroudering, veral wat navorsing en produksieprosesse betref.

Die volgende stap in die strategiese bemarkingsbeplanningsproses is om die resultate van die omgewingsverkenning te integreer in ' $n$ geskrewe bemarkingsplan wat bestaan uit die formulering van ' $n$ bemarkingsmissie en -doelwitte en ' $n$ bemarkingstrategie.

\section{'n BEMARKINGSMISSIE, -DOELSTELLINGS EN - DOELWITTE}

Kotler en Armstrong (1987:123-131), McCarthy en Perrault (1993:112-131) en Schoell en Guiltinan (1993:34, 46, 56) meen dat die geïdentifiseerde geleenthede en bedreigings in die eksterne omgewing met die sterk en swak punte in die onderneming in verband gebring moet word sodat besluit kan word watter bemarkingstrategie die beste sal wees om uitvoering aan die onderneming se missie en doelwitte te gee.

Die bemarkingsmissie kan as ' $n$ verlenging van die ondernemingsmissie beskou word. In die bemarkingsmissie kan die onderneming byvoorbeeld besluit om op groei te fokus deur nuwe produkte, of nuwe markte of ' $n$ kombinasie van beide, te ontwikkel. Op dieselfde trant kan die bemarkingsmissie oor verskeie ander bemarkingsaangeleenthede handel.

$\mathrm{Na}$ aanleiding van die bemarkingsmissie word 'n oorhoofse asook spesifieke bemarkingsdoelswitte vir die onderneming geformuleer. Doelwitte kan geformuleer word met verwysing na die mense wat bedien word, kostebesparing, fondse wat geïn word, veranderinge wat moet plaasvind, of enige ander faktore waaroor bemarkers beheer het. 
TABEL 1: VOORBEELDE VAN FAKTORE WAT GEBRUIK WORD OM VERBRUIKERSMARKTE TE SEGMENTEER (Machado, 1996:47)

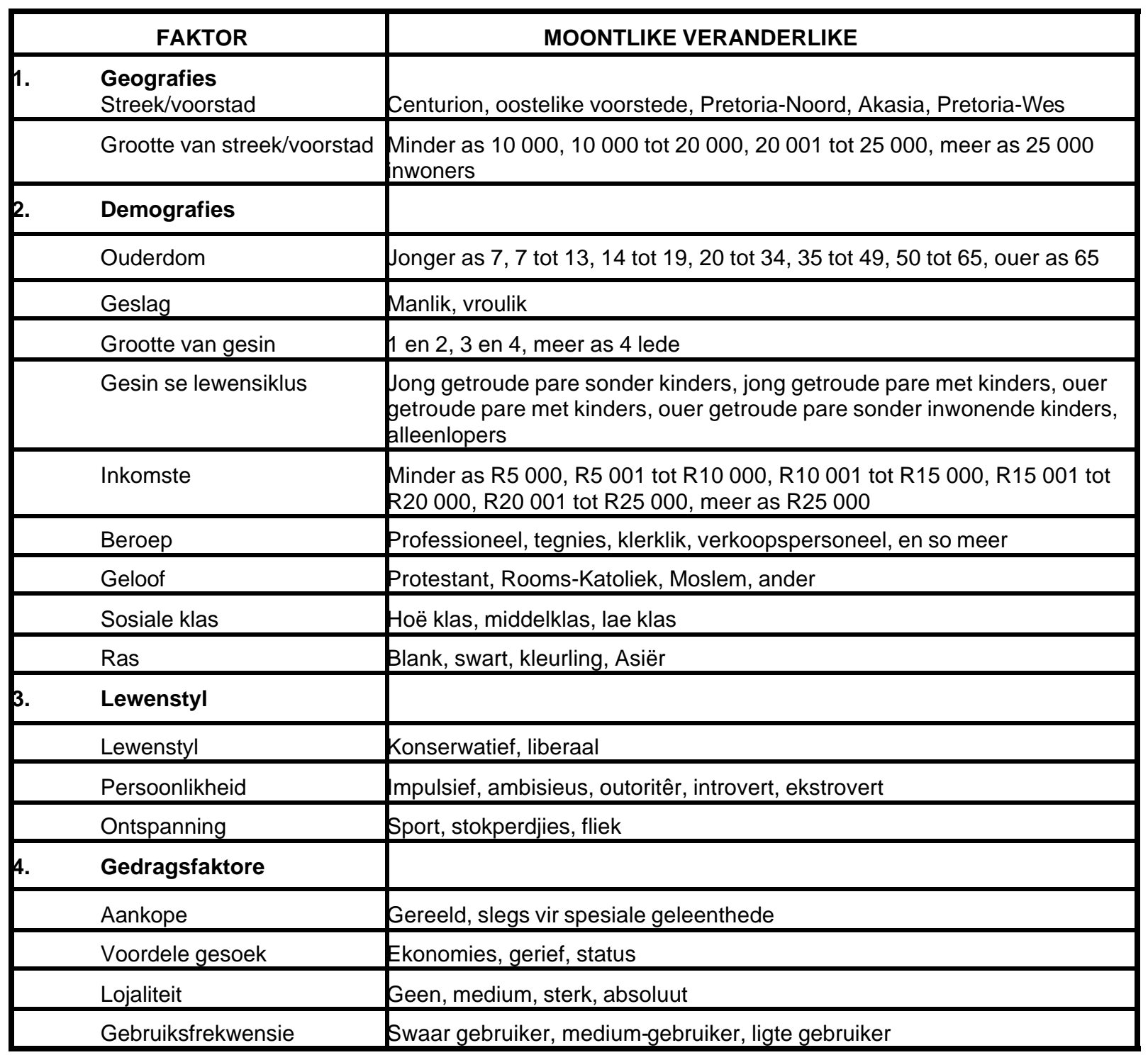

\section{BEPLANNING VAN 'n BEMARKINGSTRATEGIE}

Die bemarkingstrategie is die unieke wyse waarop 'n onderneming sy geformuleerde bemarkingsdoelwitte wil bereik. Hierdie strategie bestaan uit drie komponente:

- Segmentering van die mark om een of meer teikenmarkte te selekteer

- Bepaling van die posisie van die onderneming in verhouding tot sy mededingers, om sy produk op die mees effektiewe wyse te posisioneer

- Beplanning en koördinering van die kernbesluitnemingsgebiede, naamlik produk, prys, distribusie en bemarkingskommunikasie.

\section{Marksegmentering en doelmarkkeuse}

Marx en Van der Walt (1993:103), Stantan et al (1992:95-96), en Schoell en Guiltinan(1993:159) meen dat marksegmentering die bemarker in staat stel om ' $n$ heterogene mark in kleiner, homogene submarkte of marksegmente te verdeel sodat die verbruikers se behoeftes en eienskappe in essensie homogeen is. Die bemarker kan vir elke marksegment wat as 'n teikenmark gekies word, 'n spesifieke bemarkingsmengsel ontwikkel om hierdie spesifieke teikenmark se behoeftes optimaal te bevredig. Marksegmentering stel die bemarker in staat om die diversiteit in ' $n$ bepaalde mark raak te sien en daarby aan te pas.

Hooley en Saunders (1993:137-138) noem drie 
aannames onderliggend aan segmentering as ' $\mathrm{n}$ benadering tot bemarking:

- Verbruikers verskil van mekaar op die een of ander wyse en dit kan gebruik word om die totale mark te verdeel.

- Segmente kan op grond van meetbare eienskappe geïdentifiseer word om die potensiële waarde daarvan as 'n teikenmark te bepaal.

- Geselekteerde segmente kan geïsoleer word van die res van die mark en kan sodoende met 'n spesifiek-gerigte bemarkingspoging bereik word.

Kotler (1991:269), Stanton et al (1992:99), Hooley en Saunders (1993:138), Schoell en Guiltinan (1993:166), en Machado (1996:47) meen dat mark segmentering op een of meer van vier grondslae berus, naamlik geografiese, demografiese, psigografiese/leefstyl- en gedragseienskappe. Hierdie grondsale word kortliks in Tabel 1 toegelig.

Die doel van marksegmentering is om segmente of markte te vind waarin die onderneming kan meeding. Die gekose segmente word die onderneming se teiken- of doelmark genoem en bestaan uit 'n groep verbruikers wat bepaalde behoeftes en/of eienskappe in gemeen het.

Volgens Longenecker et al (1994:61) het die eienaar van 'n mikro-onderneming drie opsies in die besluit oor hoeveel segmente bedien gaan word:

- Massabemarkingsbenadering: Dieselfde produkte word aan die hele mark op dieselfde wyse bemark (daar is dus geen marksegmentering nie). Die onderliggende aanname hier is dat alle verbruikers dieselfde is.

- Multisegmentbenadering: Verskillende produkte word op verskillende wyses aan verskillende segmente gebied.

- Konsentrasie- of nisbemarkingsbenadering: Een produk word intensief aan een of twee klein marksegmente met baie potensiaal bemark.

Washer (1992), Machado (1996:43) en Reynecke (1995) meen dat mikro-ondernemings meer suksesvol sal wees as hulle die nisbemarkingsbenadering volg. Dit stel die mikro-onderneming in staat om te spesialiseer en om skaars hulpbronne ten beste te benut. Washer (1992) meen egter ook dat die afbakening van 'n segment waarin meegeding word, een van die groot struikelblokke is waarmee mikro-ondernemings te doen het. Hy maan sulke ondernemings om nie te gou in 'n te groot segment te wil meeding nie. Eers wanneer die onderneming vaste verbruikers het en redelik winsgewend bedryf word, kan dit oorweeg om na meer segmente uit te brei (Hoffman \& Hunt, 1993:32; Machado, 1996:43).

Volgens Adcock et al (1993:71) moet die markseg- mente wat as teikenmarkte geselekteer word, aan bepaalde kriteria voldoen:

- Die segmente moet groot genoeg wees om die bemarkingspoging te regverdig.

- Hulle moet wesenlik van mekaar verskil.

- Hulle moet bereikbaar wees.

- Die segmente moet "duursaam" wees, met ander woorde hulle moet nie gou van die toneel af verdwyn nie.

Die potensiële segmente word volgens hierdie kriteria geëvalueer en een of twee segmente word as teikenmarkte gekies. Die potensiaal van elke segment asook die hulpbronne van die onderneming word in gedagte gehou tydens die seleksieproses.

\section{Posisionering}

Nadat die onderneming 'n teikenmark geselekteer het, probeer hy om homself sodanig in hierdie gekose segment te posisioneer dat verbruikers hom as beter as sy mededingers ervaar. Die doel van posisionering is om ' $n$ mededingende voordeel te bewerkstellig sodat verbruikers glo dat hierdie produk of onderneming oor al die eienskappe beskik waarna hy of sy soek en sy of haar behoeftes ten volle sal bevredig. 'n Mikroonderneming behoort besondere aandag aan die posisioneringsbesluit te skenk aangesien posisionering die die rigting aandui wat die onderneming met sy produkte, pryse, distribusie en bemarkingskommunikasie gaan inslaan en die doel wat dit in die mark wil bereik (Levinson \& Godin, 1995:8; Machado, 1996:50).

Machado (1996:50) lys enkele kriteria waaraan posisionering moet voldoen om effektief te wees:

- Die posisioneringsbesluit van die onderneming moet duidelik aan die mark gekommunikeer word.

- Die onderneming se posisionering moet hom anders en beter as sy mededingers maak, byvoorbeeld deur die ontwerp, waarde vir geld, grootte, diens of betroubaarheid. Hierdie "anders" moet vir die verbruiker belangrik wees.

- Posisionering vind uiteindelik in die gedagtes van die verbruiker plaas. Daarom is dit belangrik dat die onderneming seker maak dat die verbruiker die onderneming se mededingende voordeel verstaan en daarin glo.

\section{Die bemarkingsmengsel}

Nadat die teikenmarkte geselekteer is, word besluite geneem oor die mees effektiewe samestelling van die vier komponente van die bemarkingstrategie, naamlik die produk, prys, plek en bemarkingskommunikasie.

Volgens Marx en Van der Walt (1993:493) dui die bemarkingstrategie aan watter doelwitte die bemarkingsbestuur wil bereik. Hierdie bemarkingsplan bestaan uit ' $n$ stel taktiese aksies wat geïntegreer en 
op die onderneming se hoofdoelwit gerig is. Produk-, prys-, distribusie- en bemarkingskommunikasiebesluite kan beskou word as die taktiek om die plan ten uitvoer te bring. Gesamentlik en geïntegreer vorm hierdie taktiek die wese van die bemarkingstrategie.

In die Engelse bemarkingsliteratuur word na hierdie komponente verwys as die "four Ps" (product, price, place, promotion) of die bemarkingsgereedskap van die bemarker. Die effektiewe samestelling van hierdie komponente staan bekend as die bemarkingsmengsel. Die implikasie is dat dié vier veranderlikes beheer kan word deur die persoon wat vir die bemarking verantwoordelik is om die vraag na sy produk te beïnvloed. Volgens Hannagan in Terblanche (1993:180) vereis elke spesifieke bemarkingsituasie ' $n$ toepaslike samestelling ten opsigte van die produk, prys, plek en bemarkingskommunikasie: An effective marketing strategy will weld the four variables together in order to satisfy customers' needs. Ideally this will have what can be described as a synergistic effect, so that the total combined effect will be greater than the sum of the parts.

Produkbesluite Die produk wat vervaardig word is baie belangrik vir die suksesvolle bedryf van die onderneming omdat die produk die vereistes/verwagtinge/behoeftes van die teikenmark bevredig en ' $n$ sleutelrol in die bereiking van die onderneming se doelwitte speel (Adcock et al, 1993:153). Zimmerer en Scarborough (1994:179) en Machado (1996:58) definieer ' $n$ produk as enige item of diens wat die verbruiker se behoefte(s) bevredig, en Pitt (1990) meen dat produkte die voordele verskaf waarna die verbruiker soek.

Marx en Van der Walt (1993:176) onderskei drie dimensies waaruit ' $n$ produk bestaan:

- Basiese of kernproduk: Dit is die voordeel of behoeftebevrediging wat die verbruiker verwag om uit die produk te kry. 'n Persoon wat klere koop, koop byvoorbeeld nie klere net om sy liggaam te bedek nie; hy koop 'n modieuse voorkoms, aanvaarding deur sy verwysingsgroep, bewondering van ander, en so meer.

- Ware produk: Dit bestaan uit die basiese of kernproduk plus al die fisiese eienskappe van die produk, byvoorbeeld die ontwerp, kleur, kleedstof, knope, versierings, handelsnaam en verpakking.

- Totale produk: Dit is die basiese of kernproduk plus die ware produk plus alle ekstras verbonde aan die produk, byvoorbeeld goeie diens, figuuranalise, klerekasbeplanning, aflewering en herstelwerk.

Die eienaar van 'n mikro-onderneming moet onthou dat dit sy onderneming se totale produk is wat met die produkte van sy mededingers meeding. Dit is dus belangrik om die totale produk te identifiseer om te kan bepaal in hoe 'n mate dit die verbruikers se behoeftes bevredig en hoe dit ' $n$ mededingende voordeel in die mark gaan bewerkstellig (Adcock et al, 1993:114).

Die produk- en diensmengsel Baie tuisondernemings wat klere vervaardig skakel direk met hul verbruikers. Hierdie ondernemings het nie net 'n produk wat hulle aan verbruikers verskaf nie, want daar is ook sprake van die lewering van 'n diens. Só 'n onderneming beskik oor 'n produk- en diensmengsel wat Hutt en Stull (1992:111-114) omskryf as die som van die produkte en/of dienste wat 'n onderneming aanbied.

Die volgende faktore het ' $n$ invloed op 'n onderneming se produk- en diensmengsel (Marx \& Van der Walt, 1993:190-195):

- Die oorkoepelende doelwitte van die onderneming: Die onderneming se doelwitte wat wins en markaandeel betref, sal bepaal hoe wyd die produk- en diensmengsel moet wees. 'n Onderneming wat besluit om eksklusiewe klere te verskaf, sal byvoorbeeld 'n produkmengsel hê wat redelik wyd en vlak is om eksklusiwiteit te behou. Dit beteken dat ' $n$ groot verskeidenheid ontwerpe aangebied word, maar dat elke ontwerp slegs een of hoogstens twee keer vervaardig word.

- Veranderinge in die mark: Verbruikers word dikwels geraak deur veranderinge in hul eie omstandighede en dit kan daartoe bydra dat hulle ander tipes produkte soek. 'n Onderneming moet deurgaans op die hoogte bly van veranderinge in sy verbruikers se behoeftes sodat hy sy produk- en/of diensmengsel daarby kan aanpas. In die klerebedryf verander modes gedurig en daarmee saam die verbruikers se klerebehoeftes. Mikro-ondernemings het ' $n$ groot voordeel bo groot ondernemings omdat hulle makliker en vinniger hul produkte op klein skaal kan verander en/of aanpas. ' $n$ Toenemende getal verbruikers vind dit deesdae geriefliker en veiliger om klere by ' $n$ kleremaakster in haar/sy spesifieke omgewing te laat maak eerder as om groot en besige winkelsentrums te besoek (Lütge-Smith, 1995:118). Die modeverbruiker raak ook verveeld met die massageproduseerde klere wat in alle kettingwinkels te kry is en soek na eksklusiewe klere. Hierdie is twee veranderinge waarby klere-vervaardigers tuis kan baat.

- Optrede van mededingers: Die optrede van en veranderinge by mededingers moet fyn dopgehou word sodat die onderneming daarop kan reageer deur byvoorbeeld sy produkte op ' $n$ ander wyse aan te bied as sy mededingers, of om selfs produkte aan te bied op gebiede waar sy mededingers nie so sterk is nie. Mikro-ondernemings kan hier groot voordeel trek deur kundige en persoonlike diens, wat nie in groot kettingwinkels bestaan nie, aan hul kliënte te bied. Sulke dienste kan voorkoms- en kleuranalise en selfs klerekasbeplanning insluit. 
- Produksieoorwegings: Die onderneming kan sy produksiefasiliteite meer effektief gebruik deur die produkmengsel aan te pas. Die klerevervaardigingsonderneming kan moontlik besluit om kinderklere van die afvalstukkies materiaal te maak wanneer daar nie baie bestellings is nie en stiksters nie teen volle kapasiteit werk nie.

Handelsnaam/merk Machado (1996:69) definieer 'n handelsmerk as 'n naam, simbool, teken, ontwerp of 'n kombinasie van die voorgaande wat die produk identifiseer. Dit is moontlik om 'n handelsmerk te registreer wat dit dan onwettig maak vir enigiemand anders om die spesifieke naam/merk te gebruik.

Washer (1993) en Reynecke (1995) beklemtoon dat mikro-ondernemings veral kan baat by die gebruik van ' $\mathrm{n}$ handelsmerk omdat dit die onderneming onmiddellik in ' $n$ ander, meer professionele klas plaas en ook ' $n$ identiteit aan die onderneming verskaf.

Reynecke (1995) en Machado (1996:71) gee die volgende riglyne wat die eienaar van 'n mikro-onderneming kan volg wanneer ' $n$ handelsnaam gekies word:

- Dit moet die produk differensieer van die produkte van mededingers.

- Dit moet met die produk versoenbaar wees.

- Dit moet verkieslik die produk beskryf.

- Dit moet maklik wees om te onthou en om uit te spreek.

- Dit moet maklik wees om te bemark en te adverteer.

- Dit moet oorspronklik wees.

- Die naam moet verkieslik 'n hoëkwaliteit-beeld uitdra.

Verpakking Wanneer ' $n$ handelsmerk of -naam vir die onderneming gekeis is, word aandag geskenk aan hoe die produk verpak gaan word. Levinson en Godin (1994:248-249) en Machado (1996:72) beskou verpakking as die ontwerp en vervaardiging van 'n "houer" of "omhulsel" vir die produk sodat die produk behoorlik beskerm, gestoor, hanteer, vervoer, geïdentifiseer en bemark kan word.

Die teikenmark moet ontleed word om te bepaal van watter tipe verpakking verbruikers sal hou voordat op die verpakking vir die produk besluit word (Reynecke, 1995). Die veranderende behoeftes/vraag van verbruikers moet in ag geneem word. Dit is op die oomblik byvoorbeeld "in" om omgewingsvriendelike verpakking te gebruik. Die kleur van die verpakking asook die inligting wat op die verpakking gaan voorkom moet weldeurdag wees.

Heelwat mikro-ondernemings "verpak" hulle klere op hangers en omhul dit in plastiek. Hoewel dit 'n sinvolle manier is om die klere te lewer, kom die handelsmerk van die vervaardiger nêrens op die verpakking voor nie. Sulke ondernemings kan moontlik spesiale plastieksakke laat druk met die handelsmerk van die onderneming daarop (soos dié wat deur droogskoonmakers gebruik word). Ander moontlikhede is bruin papiersakke met die handelsmerk op (die klere moet dan gevou word) of selfs groot, plat kartondose waarin die klere opgevou kan word. Elke mikro-onderneming behoort sy klere op die een of ander unieke, identifiseerbare wyse te verpak om sy beeld te bevorder (Washer, 1993).

Waarborg ' $n$ Waarborg is ' $n$ belofte dat 'n produk aan sekere standaarde voldoen (Machado, 1996:74). Hoewel daar nie sommer 'n waarborg vir klere gegee kan word nie, kan die voordele wat 'n waarborg bied verkry word deur ' $n$ beleid te formuleer vir omruilings en herstelwerk aan die klere. Só 'n beleid verminder die risiko vir die verbruiker omdat hy/sy weet hy/sy kan die produk vir herstelwerk terugbring. Wanneer 'n omruilings- en herstelbeleid deel vorm van die totale produk wat aan die verbruiker gebied word, ondersteun dit die beeld van kwaliteit. Die beleid moet duidelik geformuleer en aan verbruikers oorgedra word sodat die onderneming nie uitgebuit word nie. 'n Omruilings- en herstelbeleid vir mikro-ondernemings kan as volg lui:

Omruilings: Klere sal slegs omgeruil word as dit binne 'n week na aankope teruggebring word, dit nog nie gedra en versorg is nie, en die oorspronklike etikette nog op die klere voorkom. Die kliënt sal nie haar geld terugkry nie, maar sy kan 'n ander kledingstuk kies of 'n kredietnota sal aan haar uitgereik word sodat sy binne drie maande ' $n$ ander kledingstuk kan kies.

Herstelwerk: Geringe herstelwerk sal aan klere gedoen word binne die eerste maand na aankope. Hierdie herstelwerk sluit nie verstellings aan klere in nie. Dit behels die vaswerk van knope, skouerkussings, nate, some en voerings wat lostrek. Die onderneming aanvaar geen verantwoordelikheid vir die materiaal wat gebruik word nie.

Prysbesluite Die pryse van die onderneming se produkte het ' $n$ invloed op die langtermynsukses van die onderneming omdat dit implikasies het vir die wins wat gemaak word. Prysbesluite is van die belangrikste besluite wat tydens die beplanning van die bemarkingstrategie geneem word (Majaro, 1993:93). Frain (1994:176) wys daarop dat dit die een element van bemarking is wat geld genereer, terwyl die ander drie geld kos.

Faktore wat prysbepaling beïnvloed Lütge-Smith (1988) en Emmew (1993:173-178) meen dat verskeie faktore die bepaling van die regte prys beïnvloed. Dit sluit die koste van rou materiale, mededigingers en hulle pryse, die tipe produk of diens, die beeld van die onderneming, die vraag na en aanbod van die produk, omgewingsfaktore soos owerheidsregulasies, rentekoerse en invoerbelasting, die wyse waarop die teikenmark op pryse reageer en die koste verbonde aan die lewering van die produkte in. Met hierdie faktore in gedagte moet 'n fyn balans tussen oor-en onderprysing gevind word. Hoewel baie verbruikers verwag om laer pryse by mikro-ondernemings as by groot kettingwinkels te betaal, moet die mikro-onderneming daarteen waak om te lae pryse vir sy produkte te vra en sodoende die onderneming en sy produkte 
se waargenome waarde afbring (Lütge-Smith, 1988; Running a business from home ... is your right, 1993). Daarenteen moet die onderneming versigtig wees om nie te hoë pryse vir sy produkte te vra en die verbruikers daardeur af te skrik nie.

Prysbepaling Mikro-ondernemings kan verskeie metodes gebruik om pryse te bepaal. Daar word volstaan met enkele wenke in hierdie verband:

- Hou gedetailleerde besonderhede van alle uitgawes omdat alle koste in berekening gebring moet word wanneer pryse bepaal word. Hierdie koste kan die volgende insluit:

$\diamond \quad$ "Huur" vir die gedeelte van die huis of ander lokaal wat vir die onderneming gebruik word

$\diamond$ 'n Persentasie van die water- en elektrisiteitasook die telefoonrekening

$\checkmark$ Vervoer (byvoorbeeld van werkers of vir die aankoop van grondstowwe)

$\checkmark$ Koste van alle grondstowwe, byvoorbeeld materiaal, tussenbelegsel, knope, ritse, garing, naalde

$\diamond \quad$ Lone/salarisse vir stiksters

$\diamond$ Baie belangrik: 'n salaris vir die eienaar en/of bestuurder self.

Wanneer hierdie kostes bereken is, word ' $n$ winspersentasie bygetel.

- Pryse kan ook bereken word sodat die verbruikers die produkte as waarde vir geld beskou, of wat verbruikers bereid is om vir die produk te betaal. Andersyds kan prestigepryse gebruik word met ander woorde die produkte word hoog geprys om die kwaliteit of prestige daarvan aan die verbruiker te kommunikeer. Hiervolgens word aanvaar dat die verbruikers hoë pryse met hoë kwaliteit assosieer.

- Baie verbruikers is geneig om te dink dat R99,95 heelwat minder is as R100.

- Bondelpryse kan ook effektief vir mikro-ondernemings werk, byvoorbeeld R300 vir die romp en baadjie as dit saam gekoop word, maar R165 stuk as dit apart gekoop word.

- 'n Mikro-onderneming kan ook sy pryse vasstel deur na die pryse van sy mededingers te kyk. Die onderneming kan dan kies om sy pryse dieselfde of hoër of laer as dié van sy mededingers te maak.

Watter metode ook al gebruik word om pryse te bepaal, die eienaar van die mikro-onderneming moet onthou dat sy of haar produkte sodanig geprys moet word dat dit vir die verbruikers aanvaarbaar is (Pinson \& Jinnett, 1993:81).

Afslagbeleid Nadat die onderneming op 'n metode besluit het om sy pryse te bepaal, kan 'n beleid geformuleer word om voorsiening te mak vir die buigbaarheid van daardie pryse. Die volgende vorme van afslag is op mikro-ondernemings van toepassing en kan oorweeg word:

- Hoeveelheidsafslag: Afslag word gebied op grond van die aantal produkte wat die klant koop. Die idee is om klante aan te moedig om groot hoeveelhede klere op een slag te koop.

- Kontantafslag: Afslag kan vir kontantaankope aangebied word, of wanneer klante op rekening koop, kan ' $n$ afslag aangebied word as die rekening binne ' $n$ bepaalde tydperk vereffen word.

- Seisoenafslag: Dit word aangebied om verkope gedurende 'n spesifieke tyd van die dag of jaar te stimuleer. 'n Persentasie-afslag word byvoorbeeld aangebied vir alle matriekafskeidsrokke wat in Julie en Augustus bestel word.

Betalings- en kredietbeleid Elke onderneming moet ' $\mathrm{n}$ beleid met betrekking tot betaling formuleer. Die onderneming kan besluit om slegs op ' $n$ kontantbasis te werk, of om krediet in die vorm van rekeninge toe te staan. Machado (1996:100) wys daarop dat krediet die verkope van 'n onderneming kan laat toeneem deur nuwe klante te lok of bestaande klante in staat te stel om meer te koop. Mikro-ondernemings moet egter in ag neem dat verbruikers klere by die groot kettingwinkels vir ses maande rentevry op krediet kan koop. Die implementering van 'n kredietstelsel verg goeie beplanning en streng kontrole (Hoffman \& Hunt, 1993:48). Klante se kredietwaardigheid moet bepaal word alvorens krediet aan hulle toegestaan word.

Mikro-ondernemings wat klere op bestelling vervaardig, kan oorweeg om ' $n$ deposito te vra wanneer die bestelling geplaas word. Hierdie deposito kan tot soveel as $50 \%$ van die totale gekwoteerde prys bedra. Wanneer klante egter hul eie materiaal verskaf, kan die materiaal as deposito op die bestelling beskou word.

Distribusiebesluite Distribusie is die stelsel wat die onderneming se produkte kry waar die verbruiker dit wil koop (Machado, 1996:108). Die produkte vloei deur ' $n$ distribusiekanaal bestaande uit mense en ondernemings (middelmanne of tussengangers) wat die produkte van die vervaardiger tot by die verbruiker vervoer (Hutt \& Stull, 1992:310).

Die distribusiekanaal 'n Distribusiekanaal kan direk of indirek wees. Met 'n direkte distribusiekanaal lewer die vervaardiger sy produkte direk aan die verbruiker, terwyl daar in die geval van 'n indirekte distribusiekanaal een of meer middelmanne tussen die vervaardiger en die verbruiker is (Longenecker et al, 1994:383). Mikro-ondernemings kan op enige van dié distribusiekanale besluit. Baie ondernemings verkies om van 'n direkte distribusiekanaal gebruik te maak omdat persoonlike kontak met die verbruiker behou word en ook omdat pryse relatief laag gehou kan word. Daar bestaan drie alternatiewe direkte distribusiekanale vir mikro-ondernemings: 
- Die onderneming ontvang sy klante by sy perseel, waar die verkope plaasvind.

- Die onderneming maak van partytjieverkope gebruik waar 'n gasvrou 'n aantal mense nooi en die eienaar die produkte aan huis van die gasvrou uitstal en verkoop.

- Die onderneming verkoop sy produkte op 'n vlooimark.

Daar is ook drie opsies vir mikro-ondernemings wat verkies om van 'n indirekte distribusiekanaal gebruik te maak naamlik:

- Die eienaar van die onderneming verkoop self die produkte aan kleinhandelaars soos boetieks wat hulle dan aan die verbruiker verkoop.

- 'n Agent verkoop die ondernemnig se produkte aan kleinhandelaars en word op ' $n$ kommissiebasis vergoed.

- Die mikro-onderneming tree op as 'n CMT (cut, make and trim) onderneming vir groot kettingwinkelgroepe. In hierdie geval skakel die mikro-onderneming nie direk met die kleinhandelaar nie, maar kry sy bestellings deur een van die kleinhandelsgroep se geregistreerde verskaffers en lewer die klaar produkte aan die verskaffer.

'n Aantal faktore beïnvloed die keuse van 'n geskikte distribusiekanaal:

- Eienskappe van die teikenmark: grootte, ligging, voorkeure en tipe verbruiker

- Produkkenmerke: prys, produkte wat spesifiek volgens die verbruiker se spesifikasies gemaak is, produkte wat gespesialiseerde diens vereis

- Eienskappe van die vervaardiger: interne hulpbronne, geskikte verkoopspersoneel, bemarkingskennis/oriëntering

- Omgewingsfaktore: wetgewing, stand van die ekonomie, tegnologie.

Ligging 'n Laaste aspek wat vir distribusiebesluite oorweeg word, is die ligging van die mikro-onderneming. Toeganklikheid vir verbruikers en die beskikbaarheid van hulpbronne moet oorweeg word wanneer oor die ligging van die mikro-onderneming besluit word.

Die eienaar van ' $n$ mikro-onderneming moet hom- of haarself vergewis van bepaalde voorskrifte en vereistes wat op die gekose ligging van toepassing is, hetsy of die onderneming van die huis af bedryf word en of dit in ' $n$ nywerheidsgebied of ' $n$ winkelsentrum geleë is.

Bemarkingskommunikasiebesluite Bemarkingskommunikasie bestaan uit al die metodes waarvan die mikro-onderneming gebruik maak om met sy teikenmark te kommunikeer, byvoorbeeld advertensies, verkoopspromosies, publisiteit en persoonlike verkope. Hierdie metodes word ingespan om 'n bepaalde beeld by die verbruiker van die mikro-onderneming se produkte te skep.

Die oogmerke van suksesvolle bemarkingskommunikasie is drieledig:

- Om in te lig: Verskaf inligting oor die produk aan die verbruiker, maak die verbruiker bewus van die bestaan van die produk, lig die verbruiker in oor waar die produk verkry kan word.

- Om te oorreed: Poog om 'n positiewe houding teenoor die produk by die verbruiker te kweek, en vertel aan verbruikers waarom hulle die produk liewer as díe van mededingers moet koop.

- Om te herinner: Herinner verbruikers wat reeds by die onderneming gekoop het aan die onderneming en vestig lojaliteit by gereelde klante.

Geskikte vorme van bemarkingskommunikasie 'n Beperkte begroting moet vir bemarkingskommunikasie en ook die teikenmark van die mikro-onderneming in ag geneem word. Omdat die teikenmark waarskynlik redelik plaaslik is, is die volgende vorme van bemarkingskommunikasie vir mikro-ondernemings geskik:

- Advertensies: Die mikro-onderneming kan oorweeg om in 'n plaaslike of streekskoerant te adverteer, selfs by die geklassifiseerde advertensies. Lütge-Smith (1988) wys daarop dat so 'n advertensie meer as een keer geplaas moet word om goeie resultate te verseker.

- Verkoopspromosies: Dit sluit aspekte in soos deelname aan 'n modeparade vir liefdadigheid, die skenking van 'n uitrusting by 'n spesiale geleentheid, die borg van een of ander gebeurtenis, byvoorbeeld 'n mode-ontwerpkompetisie.

- Publisiteit: Publisiteit behels inligting oor die mikro-onderneming wat as ' $n$ nuus-item of ' $n$ artikel gepubliseer word (Longenecker et al, 1994:374). Indien die mikro-onderneming iets unieks maak of 'n demonstrasie beplan, kan die plaaslike koerant genader word om ' $n$ artikel oor die onderneming te skryf en dit sodoende te adverteer (Lütge-Smith, 1988).

- Persoonlike verkope: Vir die mikro-onderneming wat van 'n direkte distribusiekanaal gebruik maak, is persoonlike verkope en diens aan die klant van onskatbare waarde. Tevrede verbruikers gaan graag terug na 'n plek waar hulle goeie diens ontvang het en sal moontlik ' $n$ vriendin of twee saambring of hulle van die onderneming en sy produkte vertel. Een van die magtigste vorme van bemarkingskommunikasie is sekerlik mondeling oftewel persoonlike "getuigskrifte" van bestaande 
verbruikers aan potensiële verbruikers.

- Reklamemateriaal: Reklamemateriaal vir die klein onderneming moet nie onderskat word nie LütgeSmith (1988); Running a business from your home ... is your right, (1993); Washer (1993). Hierdie reklamemateriaal kan professioneel ontwerpte en hoëkwaliteit-visitekaartjies, briefhoofde, brosjures of pamflette, bestelvorms, kwitansieboeke, en nog vele meer insluit. Sulke reklamemateriaal maak ' $n$ groot bydrae tot die professionele beeld van die onderneming en daarom is 'n handelsmerk en/of logo daarop besonder belangrik.

Meting van resultate Die effektiwiteit van elke vorm van bemarkingskommunikasie wat gebruik word, moet gemeet word om te bepaal of dit die moeite en die geld werd was. Dit hoef nie noodwendig formeel gedoen te word nie. 'n Advertensie in 'n koerant kan byvoorbeeld $20 \%$ afslag aanbied op produkte wat gekoop word as dié bepaalde advertensie aan die eienaar en/of bestuurder getoon word. Die eienaar en/of bestuurder kan ook aan elke nuwe verbruiker vra waar hy/sy van die onderneming te hore gekom het.

\section{SAMEVATTING}

Die eienaar van ' $n$ mikro-onderneming behoort al die aspekte van ' $n$ bemarkingstrategie wat in hierdie artikel genoem is formeel in ' $n$ bemarkingsplan saam te vat. Volgens McDonald en Tideman (1993:14) hou 'n formele bemarkingsplan die volgende voordele in:

- Dit dwing die eienaar om sy of haar bemarking op 'n georganiseerde wyse te benader.

- Dit stel 'n spesifieke toekomsrigting vir die onderneming daar.

- Dit lei daartoe dat die onderneming konsekwent in verskillende situasies optree.

- Dit stel bepaalde doelwitte wat die onderneming moet bereik.

Wanneer die bemarkingsplan opgestel is, word dit geïmplementeer en gevolg. Die effektiwiteit van hierdie bemarkingsplan moet van tyd tot tyd geëvalueer word sodat regstellende stappe vroegtydig gedoen kan word om sukses te verseker.

\section{LITERATUURVERWYSINGS}

ADCOCK, D, BRADFIELD, R, HALBORG, A \& ROSS, C (1993): Marketing principles and practice. London. Pitman. BAKER, J (1992): The Changing Market. The Buyer 60 (4):30-39.

DENISON, DR (1990): Corporate culture and organizational effectiveness. New York. Wiley.

ENNEW, CT (1993): The marketing blueprint. Oxford. Blackwell.

FRAIN, J (1994): Introduction to marketing. 3rd ed. London. Pitman.

HICKMAN, CR \& SILVA, MA (1988): Creating excellence: managing corporate culture, strategy and change in the new age. 2nd ed. London. Unwin.

HOFFMANN, B \& HUNT, B (1993): Marketing creative clothing. Bolder. B \& H Publishing.

HOOLEY, GH \& SAUNDERS, J (1993): Competitive Positioning - The key to marketing strategy. New York. Prentice-Hall.

HUTT, RW \& STULL, WA (1992): Marketing: an introduction. Cincinnati. South-Western.

KAPLAN, C (1989): There's a lipstick in my briefcase - a guide for the new woman entrepreneur. Sydney. Godiva. KOTLER, P (1984): Marketing essentials. Englewood Cliffs, NJ. Prentice-Hall.

KOTLER, P (1991): Marketing Management - analysis, planning, implementation and control. Englewood Cliffs, NJ. Prentice-Hall.

KOTLER, P \& ANDREASEN, P (1991): Strategic Marketing for Non-profit Organizations. Englewood-Cliffs, NJ. Prentice-Hall.

KOTLER, P \& ARMSTRONG, G (1987): Marketing - An Introduction. Englewood Cliffs, NJ. Prentice-Hall.

LEVINSON, JC \& GODIN, S (1994): The querilla marketing handbook. New York, Houghton Mifflin.

LEVINSON, JC \& GODIN, S (!995): Guerilla marketing for the home-based business. New York, Houghton Mifflin.

LONGENECKER, JG, MOORE, CW \& PETTY, JW (1994):

Small business management: an entrepreneurial emphasis. 9th ed. Cincinnati. South-Western.

LOVELOCK, CH (1984): Services marketing: text, cases and readings. Englewood Cliffs, NJ. Prentice-Hall.

LüTGE-SMITH, T (1988): Marketing your home business. Small Business News February:12.

LüTGE-SMITH, T (1995): Working from Home - a Complete South African Guide. 3rd ed. Wynberg, Sandton. Struik. MACHADO, R (1996): Small Business Management Series - Marketing for a Small Business. Kenwyn. Juta. MAJARO, S (1993): The essence of marketing. London. Prentice-Hall.

MARX, S, RADEMEYER, WF \& REYNDERS, HJJ (1991): Bedryfsekonomie: Riglyne vir ondernemingsbestuur. Kaapstad. Van Schaik.

MARX, S \& VAN DER WALT, A (eds) (1993): Marketing Management. 2nd ed. Cape Town. Juta.

McCARTHY, EJ \& PERREAULT, WD (1993): Basic Marketing - a global-managerial approach. Boston. Irwin.

McDONALD, MHB (1992): The marketing planner. Oxford. Butterworth-Heineman.

McDONALD, MHB \& TIDEMAN, CCS (1993): Retail marketing plans: how to prepare them, how to use them. Oxford. Butterworth-Heineman.

PEARCE, JA \& ROBINSON, RB (1985): Strategic Management. 2nd ed. Homewood, III. Irwin.

PINSON, L \& JINNETT, J (1993): Target marketing for the small business. Dover. Upstart.

PITT, L (1990): Writing the strategic marketing plan. Marketing Mix April:29-31.

REYNECKE, $R$ (1995): Packaging: Often Crucial in Attracting a Buyer. Chamber Digest 15(April): 6 .

ROGERS, L (1991): Marketing for the Small Business. Oxford. Blackwell.

RUNNING A BUSINESS FROM HOME ... IS YOUR RIGHT (1993): Small Business World 1(1):18.

SCHOELL, WF \& GUILTINAN, JP (1993): Marketing Essentials - Mastering concepts and practices. Boston.

Allyn \& Bacon.

SMIT, T (1997): Bemarkingsprakrtyke van tuis-gebaseerde mikro-ondernemings in die klerevervaardigingsbedryf. Tydskr Dieetk \& Huishk 25(2):82-89.

STANTON, W, ETZEL, M, WALKER, B, ABRATT, R, PITT, L \& STAUDE, G (1992): Marketing management in South Africa. Johannesburg. Lexicon. TERBLANCHE, SS (1993): 'n Bemarkingsbenadering tot die ondersteuning en benutting van maatskaplikewerk-dienste: beginsels en riglyne. Dverhandeling. Randse Afrikaanse Universiteit.

VAN DER WALT, A, STRYDOM, JW, MARX, $S$ \& JOOSTE, CJ (red) (1996): Bemarkingsbestuur. 3de uitg. Kenwyn. Juta.

WASHER, L (1992): Marketing 101: finding your first customer. Working Woman 10:53-54, 65.

WASHER, L (1993): Building a Big Image for a Small Company. Working Women 18(3):49, 89.

ZIMMERER, TW \& SCARBOROUGH, NM (1994): Essentials of small business management. New York. Macmillan. 